\title{
Petrophysical characterization of the lacustrine sediment succession drilled in Lake El'gygytgyn, Far East Russian Arctic
}

\author{
A. C. Gebhardt ${ }^{1}$, A. Francke ${ }^{2}$, J. Kück ${ }^{3}$, M. Sauerbrey ${ }^{2}$, F. Niessen ${ }^{1}$, V. Wennrich ${ }^{2}$, and M. Melles ${ }^{2}$ \\ ${ }^{1}$ Alfred Wegener Institute Helmholtz Centre for Polar and Marine Research, Columbusstraße, 27515 Bremerhaven, Germany \\ ${ }^{2}$ University of Cologne, Institute of Geology and Mineralogy, Zülpicher Straße 49A, 50674 Cologne, Germany \\ ${ }^{3}$ German Research Centre for Geosciences, Telegrafenberg, 14473 Potsdam, Germany
}

Correspondence to: A. C. Gebhardt (catalina.gebhardt@awi.de)

Received: 17 December 2012 - Published in Clim. Past Discuss.: 18 January 2013

Revised: 17 June 2013 - Accepted: 3 July 2013 - Published: 16 August 2013

\begin{abstract}
Seismic profiles of Far East Russian Lake El'gygytgyn, formed by a meteorite impact some 3.6 million years ago, show a stratified sediment succession that can be separated into subunits $\mathrm{Ia}$ and $\mathrm{Ib}$ at approximately $167 \mathrm{~m}$ below lake floor (= $3.17 \mathrm{Ma})$. The upper (Ia) is wellstratified, while the lower is acoustically more massive and discontinuous. The sediments are intercalated with frequent mass movement deposits mainly in the proximal areas, while the distal region is almost free of such deposits at least in the upper part. In spring 2009, a long core drilled in the lake center within the framework of the International Continental Scientific Drilling Program (ICDP) penetrated the entire lacustrine sediment succession down to $\sim 320 \mathrm{~m}$ below lake floor and about $200 \mathrm{~m}$ farther into the meteorite-impactrelated bedrock. Downhole logging data down to $390 \mathrm{~m}$ below lake floor show that the bedrock and the lacustrine part differ significantly in their petrophysical characteristics. The contact between the bedrock and the lacustrine sediments is not abrupt, but rather transitional with a variable mixture of impact-altered bedrock clasts in a lacustrine matrix. Physical and chemical proxies measured on the cores can be used to divide the lacustrine part into five different statistical clusters. These can be plotted in a redox-condition vs. input-type diagram, with total organic carbon content and magnetic susceptibility values indicating anoxic or oxic conditions and with the $\mathrm{Si} / \mathrm{Ti}$ ratio representing more clastic or more biogenic input. Plotting the clusters in this diagram allows identifying clusters that represent glacial phases (cluster I), super interglacials (cluster II), and interglacial phases (clusters III and IV).
\end{abstract}

\section{Introduction}

The Arctic region is highly susceptible to global change and, at the same time, plays a major role in the global climate system through feedback processes in the oceans, the atmosphere, and the cryosphere. Accordingly it is important to understand past climate changes under different climateforcing conditions in order to make accurate predictions about future climate development. Lakes of the higher latitudes are sparsely investigated even though they are highly sensitive to shifts in climatological and environmental conditions (e.g. temperature, precipitation, insolation, vegetation, ice coverage), and as such they are valuable tracers of climate change. This lack of investigation is mainly due to their remote locations and the logistical challenges of reaching these study sites. Lakes in the high Arctic are often characterized by long winters resulting in long periods of ice coverage, followed by a short open-water season. Furthermore, many lakes of the high Arctic are subject to glacial overprint and potentially do not contain long-term terrestrial paleoclimate records.

Lake El'gygytgyn (Fig. 1) provides a unique opportunity to investigate paleoclimate conditions of the Arctic realm reaching back 3.6 million years, approximately one million years prior to the first major glaciation of the Northern Hemisphere. The lake provides records of a reasonably high resolution for resolving climate fluctuations on orbital to centennial time scales (Melles et al., 2012). Until now, only a few terrestrial records with such a high temporal resolution are known from the Arctic realm (e.g. the Greenland ice cores, Dansgaard et al., 1993; Grootes et al., 1993; Svensson et al., 


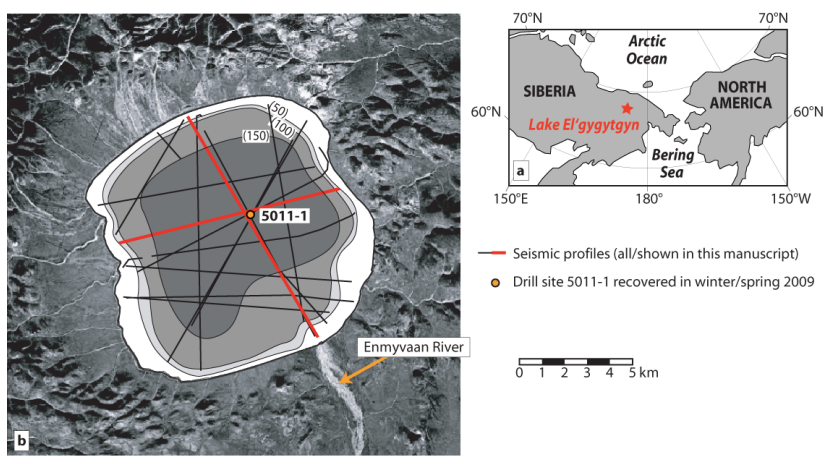

Fig. 1. Geographical map of the investigation area. (a) Location of Lake El'gygytgyn in NE Russia; (b) aerial photograph of the lake surroundings with lake bathymetry and seismic profiles. The profiles marked in red are shown in Figs. 2 and 3. The orange arrow marks the Enmyvaan River, the only outlet of the lake. Drill site ICDP 5011-1 is shown as an orange circle.

2011; NGRIP members, 2004), but none of them extends continuously to the onset of the Northern Hemisphere glaciation (Brigham-Grette et al., 2013). Marine records of the Arctic Ocean in general reach back much further in time, but show a lower temporal resolution (e.g. Lomonosov Ridge, Moran et al., 2006; Yermak Plateau, Myhre et al., 1995).

Lake El'gygytgyn is one of only a handful of lakes that formed inside a meteorite impact crater (Lerman et al., 1995). When the meteorite hit the target area 3.6 million years ago (Layer, 2000), the Northern Hemisphere was experiencing the rather constant, moderate to warm climate of the midPliocene (Harris, 2005; Repenning and Brouwers, 1987). According to Harris (2005), the Arctic Ocean was unfrozen at that time, and Boreal cedar forests covered the landside along the Arctic Ocean coasts (Repenning and Brouwers, 1987). At around 3 million years before present, the Boreal forests were replaced by tundra around the Bering Strait and inland (Harris, 2005; Brigham-Grette et al., 2013). Herman and Hopkins (1980) reported a sharp change in the sedimentation regime as well as the first occurrence of ice-rafted debris (IRD) in the Arctic Ocean from about 2.53 Ma, and the onset of large-scale glaciation in Scandinavia (by means of a marked increase in IRD flux) was dated to $2.75 \mathrm{Ma}$ by Fronval and Jansen (1996) and Jansen et al. (2000). Since then, the Arctic realm has experienced several advances and retreats of glaciers and ice sheets. A dropstone which was found in sediments as old as $45 \mathrm{Ma}$ and the frequent occurrence of IRD since the early Miocene in a marine record from the Lomonosov Ridge show that the onset of the transition from a greenhouse world to colder climate with sea ice and icebergs might have begun much earlier than hitherto assumed (Moran et al., 2006).

The El'gygytgyn area has never been subjected to glacial overprint since its formation (Glushkova and Smirnov, 2007), and, thus, the lake contains an undisturbed climate record of approximately 3.6 million years, unique for the terrestrial Arctic realm. This record was drilled within the framework of the International Continental Scientific Drilling Program (ICDP). A permafrost core (ICDP site 5011-3) was retrieved from the eastern shoreline in late autumn 2008, and during winter/spring 2009 a 517 m-long drill core (ICDP site 50111) containing lacustrine sediments and the impact-related bedrock underneath was retrieved from the ice cover of the lake (Melles et al., 2011).

This paper aims to characterize the lacustrine part of core 5011-1 as well as the transitional zone between the lacustrine sediments and the impact-related bedrock by means of petrophysical parameters such as physical properties and downhole logging measurements. These findings are then compared to the facies description by Melles et al. $(2007,2012)$ and Brigham-Grette et al. (2013) and their interpretation contained therein.

\section{General settings of the investigation area}

\subsection{Study area}

Lake El'gygytgyn $\left(67^{\circ} 30^{\prime} \mathrm{N}, 172^{\circ} 05^{\prime} \mathrm{E}\right)$ is located about $100 \mathrm{~km}$ north of the Arctic Circle in central Chukotka, NE Russia (Fig. 1). It was formed by a meteorite impact that was dated using ${ }^{40} \mathrm{Ar} /{ }^{39} \mathrm{Ar}$ to about 3.6 million years (Layer, 2000; Gurov et al., 1979a, b; Belyi, 1998). The lake's surface lies at about $490 \mathrm{~m}$ above sea level and the surrounding crater rim reaches elevations of $\sim 900$ to $1000 \mathrm{~m}$ a.s.l.

The lake is roughly circular with a diameter of $12 \mathrm{~km}$. Its catchment is limited to the crater rim with a total surface of $293 \mathrm{~km}^{2}$ in total, including lake surface. About 50 small ephemeral creeks drain into the lake (Nolan and BrighamGrette, 2007). The Enmyvaan River at the southern edge of the lake is its only outflow (Fig. 1a). The lake has a bowlshaped form with a flat, central plain of $170 \mathrm{~m}$ water depth and flanks that are steepest in the north and northeast. A shelf of 10 to $12 \mathrm{~m}$ water depth has developed in the southeastern, southern, and southwestern to western areas of the lake (Fig. 1a).

The lake is presently ice-covered for 9-10 months annually with only a short period of completely open water (Nolan and Brigham-Grette, 2007). During the short summer season, the monomictic and ultra-oligotrophic lake gets mixed completely (Nowaczyk et al., 2002; Nolan and Brigham-Grette, 2007). The catchment vegetation consists mainly of moss tundra interspersed by few shrub willows; the modern tree line lies about $150 \mathrm{~km}$ further south and west (Nowaczyk et al., 2002). The current wind system exhibits a bipolar mode with winds approximately from north and south (Nolan and Brigham-Grette, 2007). 


\subsection{Lithological succession}

In spring 2009, three drill cores were retrieved from the center of Lake El'gygytgyn (site 5011-1, cores 5011-1A, 1B, 1C) down to a maximum depth of $517.3 \mathrm{~m}$ below lake floor (b.l.f.). A detailed description of all drilling details is given by Melles et al. (2011). The cores were transported to the laboratory facilities at the University of Cologne, Germany, where they were opened and described. Based on the core description together with several measured paleoclimate proxies, a composite profile was defined (Melles et al., 2012; Nowaczyk et al., 2013). The composite sediment core consists mainly of highly variable silty-clayey pelagic sediments divided into different facies types by Melles et al. (2012) and Brigham-Grette et al. (2013), interfingered with mass movement deposits (Sauerbrey et al., 2013).

"Facies A" consists of fine clastic laminations of less than $5 \mathrm{~mm}$ thickness (average is $\sim 0.2 \mathrm{~mm}$ ). The sediments of facies type A are mainly dark gray to black in color. This suggests a stratified water column and anoxic bottom water conditions (Melles et al., 2012). The authors associate this facies type with peak glacial conditions and a perennial ice cover of the lake, with mean annual air temperatures of at least 4 $( \pm 0.5)^{\circ} \mathrm{C}$ less than today. This facies was already described in pilot core PG1351 as subunits 3 ("cold \& dry") and 4 ("cold \& moist"), characterized by enhanced amounts of total organic carbon (TOC), medium to low biogenic silica content (Melles et al., 2007), and low magnetic susceptibility due to dissolution of magnetite by anoxic conditions (Nowaczyk et al., 2007). The cold \& dry subtype is further referred to as $\mathrm{A}_{\mathrm{d}}$, the cold \& moist subtype as $\mathrm{A}_{\mathrm{m}}$. Facies A sediments are limited to the younger part of the sediment record (BrighamGrette et al., 2013), i.e. the uppermost $\sim 124 \mathrm{~m}(<2.6 \mathrm{Ma})$.

"Facies B" is the most abundant facies type in the composite profile and mainly consists of olive gray to brown, massive to faintly banded silt with greenish bands typically $1-$ $3 \mathrm{~cm}$ thick. The sediments are characterized by a lack of sedimentary structures, indicating bioturbation and oxygenated bottom water (Melles et al., 2012). This implies warmer climate with ice-free summers and a mixed water column. This facies reflects a wide range of glacial to interglacial settings including the modern situation. TOC content is rather low in facies type B $(0.83 \pm 0.27 \%)$ due to high organic matter decomposition in oxic bottom water conditions; biogenic silica values are intermediate to high due to enhanced primary productivity, and magnetic susceptibility is high reflecting good preservation of magnetite (Melles et al., 2012).

"Facies C" is the least common facies type found in the composite profile (Melles et al., 2012). It is irregularly distributed and consists of distinctly reddish-brown silt. Melles et al. (2012) suggest oxidation of bottom sediments by a well-ventilated water column as responsible for the distinct reddish color. This facies type was interpreted as representing "super interglacial" conditions e.g. during extraordinary warm MIS11 and 31, along with a number of earlier interglacials (Melles et al., 2012). Distinct laminae are found in facies type $\mathrm{C}$, probably pointing at winter stratification and anoxic bottom water conditions under a seasonal ice cover. This is further supported by high TOC values. Biogenic silica content is also exceptionally high due to diatom blooms probably caused by enhanced nutrient influx from the catchment. Magnetic susceptibility is rather low both due to dilution of the magnetic susceptibility signal by the high biogenic silica content and partial dissolution of magnetite during periods (winters) with anoxic bottom water conditions.

"Facies D" is laminated similar to facies A, but its laminae are significantly thicker with an average thickness of up to $\sim 1 \mathrm{~cm}$. Laminae are characterized by distinct lower boundaries and a fining upward sequence from silt to clay with a higher total clay content than in facies A. Facies D is mostly gray but has some red and green hues in its oldest parts. The well-preserved laminations suggests a lack of bioturbation of the bottom sediment, and the characteristic fining upward sequences in each lamina suggest repeated pulses of sediment delivery to the lake, probably due to variations in fluvial input (Brigham-Grette et al., 2013). Facies D is limited to the Pliocene part of the record, with the youngest occurrence at $\sim 141$ m b.l.f. $(\approx 2.9 \mathrm{Ma})$.

"Facies E" comprises the transition from the impactaltered bedrock to lacustrine sediments. This transition is more/less gradual with sediments composed of impact breccia and impact melt blocks in a matrix of lacustrine sediments, with the bedrock-related particles being dominant in the lower and the lacustrine sediments in the upper part (Koeberl et al., 2013; Raschke et al., 2012).

"Facies F" comprises a wide variety of mass movement deposits such as turbidites, debrites, slumps, slides and grain flows. A detailed description of the mass movement deposits and their distribution within the record is given by Sauerbrey et al. (2013). Only thin mass movement deposits $(<5 \mathrm{~cm}$ in thickness) were sampled in the composite profile of 5011-1, and thicker ones were omitted. These thinner mass movement deposits are almost exclusively turbidites.

\section{Data acquisition and processing}

\subsection{Seismic data}

Prior to deep drilling, two seismic site surveys were carried out in 2000 and 2003. In 2000, a single-channel survey was carried out using a Bolt $600 \mathrm{~B}$ airgun $\left(82 \mathrm{~cm}^{3}, 6 \mathrm{~s}\right.$ shot interval resulting in approximately $8 \mathrm{~m}$ shot distance) with a 20-element single-channel hydrophone streamer (Geoacoustics AE5000) as receiver (Niessen et al., 2007). Singlechannel reflection data were bandpass-filtered (100-150-350$450 \mathrm{~Hz}$ ), and an AGC was used for display. In 2003, two single-channel and eight multi-channel profiles were acquired using a Mini-GI gun triggered in G-gun mode at a pressure of $110 \mathrm{bar}\left(426 \mathrm{~cm}^{3}, 10 \mathrm{~s}\right.$ shot interval resulting 
in approximately $12 \mathrm{~m}$ shot distance). For the multi-channel profiles, a 14-channel streamer with an offset of $130 \mathrm{~m}$ and a hydrophone spacing of $10 \mathrm{~m}$ was used as receiving array (details are given in Niessen et al., 2007). Multi-channel data were processed in a standard sequence including bandpass filtering (70-90-240-300 Hz), velocity analysis, CMP stacking, and predictive deconvolution. Tracklines are shown in Fig. 1.

\subsection{Core physical properties}

Physical properties data of cores 5011-1A, 1B and 1C were acquired using a Geotek Multi-Sensor Core Logger (MSCL; Geotek Ltd., UK) both in the field laboratory during the drilling campaign in 2009 (magnetic susceptibility measurements on whole cores) and at the Alfred Wegener Institute (AWI) in Bremerhaven, Germany, between October 2009 and January 2011 (density measurements on split cores). The data were complemented with density and magnetic susceptibility data from pilot core Lz1024 which were measured at AWI in March 2004 on whole cores.

Magnetic susceptibility (MS) was measured in SI units using a Bartington MS-2 meter equipped with a loop sensor of $80 \mathrm{~mm}$ internal diameter. Data correction was done with respect to the specific core and loop sensor diameters according to the Bartington Manual (Geotek, 2000). Even though temperature inside the field lab container was sometimes variable due to opening and closing of the door, with inside temperatures around $+20^{\circ} \mathrm{C}$ and outside temperatures between -45 and $-20^{\circ} \mathrm{C}$, no severe drifting of the temperature-sensitive sensor was observed. The small drifting that occurred was significantly lower than the lowest susceptibility readings and, thus, did not affect the data. Both magnetic susceptibility and density data were corrected for outliers, and composite profiles were spliced accordingly to the sampling scheme used for the discrete samples (Wennrich et al., 2013)

Gamma-ray density (GRAPE) was measured using a ${ }^{137} \mathrm{Cs}$ source mounted on the Geotek MSCL. For density calibration, standard core-size semi-cylinders consisting of different proportions of aluminum and water were logged prior to the cores according to the method described by Best and Gunn (1999) but modified for split cores. Split cores were only approximately $33 \mathrm{~mm}$ thick, which is too thin for the AWI Geotek MSCL to measure thickness reliably. To convert raw gamma ray attenuation counts to density, however, exact thickness measurements are required. Accordingly we used the surface scans that were measured by the ITRAX XRF core scanner (COX Analytical Systems, Sweden) at the University of Cologne (see Wennrich et al., 2013) in the course of the XRF measurements on the same split cores. These surface scans were calibrated for thickness using a semi-cylindrical piece with a radius of $33.15 \mathrm{~mm}$ to simulate a standard split core, and three pieces that were thicker $(+10 \mathrm{~mm},+20 \mathrm{~mm})$ or thinner $(-10 \mathrm{~mm})$ than the standard to calibrate the entire range of possible sediment thicknesses.
GRAPE was calculated using the standard method (Geotek, 2000).

\subsection{Downhole logging data}

While drilling hole 5011-1C, operations were stopped four times to allow for the acquisition of downhole logging data. All data presented here were acquired using slimhole probes manufactured by Antares (Germany). Operation of the probes under the extreme conditions of an Arctic winter drilling campaign went well overall but also took its toll in the damaging of two probes: the acoustic velocity and the caliper probe. For downhole logging sessions, the pipe was pulled out of the hole, except for the uppermost approximately $20 \mathrm{~m}$ where the casing was pushed into the sediment for stabilization, leaving a sufficiently stable borehole wall. After downhole logging sessions were finished, the pipes were redeployed, and drilling operations were resumed. For drilling operations, bentonite was used as drilling fluid. Downhole logging was carried out to a maximum depth of $394 \mathrm{~m}$ below lake floor. In order to fit the downhole logging depths to the composite profile depths, the entire downhole logging dataset was shifted downwards by $3 \mathrm{~m}$. This results in an apparent discrepancy with depths used by the community working on the impact-related bedrock (e.g. Koeberl et al., 2013; Raschke et al., 2012); accordingly those depths were also shifted by $3 \mathrm{~m}$ downwards for comparison with the sediment section data. Both electrical resistivity and magnetic susceptibility data of the uppermost approximately $143 \mathrm{~m}$ could not be used as they were disturbed by the pipes of nearby abandoned holes $1 \mathrm{~A}$ and $1 \mathrm{~B}$.

Electrical resistivity (ER) of the surrounding sediments/rock at two different lateral distances from the borehole wall (deep $\sim 60 \mathrm{~cm}$ and shallow $\sim 20 \mathrm{~cm}$, with the actual penetration depending on rock porosity and the resistivity of fluid and rock) was measured using a dual laterolog probe. The probe has a vertical resolution of approximately $10 \mathrm{~cm}$ (electrode length: $8 \mathrm{~cm}$ ), and typical logging speed was $12 \mathrm{~m} \mathrm{~min}^{-1}$.

Borehole magnetic susceptibility (BMS) was measured using a probe that consists of a receiver coil and a transmitter coil that is located $20 \mathrm{~cm}$ above the former inside a non-magnetic pressure housing. The transmitter coil induces a $1 \mathrm{kHz}$ alternating magnetic field. Magnetic susceptibility was corrected for the two different borehole diameters drilled during the Lake El'gygytgyn deep drilling project. Down to $274.33 \mathrm{~m}$ composite depth (i.e. $443 \mathrm{~m}$ below lake surface), a bit size of $124 \mathrm{~mm}$ was used; a correction factor of 1.4 was applied for this section. In the deeper part of the hole, a smaller bit size of $98 \mathrm{~mm}$ was used for drilling/coring, and accordingly a correction factor of 1.25 was used. The vertical resolution is approximately $20 \mathrm{~cm}$ (detector spacing), but relative variations can be identified with a resolution of about $5 \mathrm{~cm}$. Penetration into the sidewall is $\sim 20 \mathrm{~cm}$; typical logging speed was $8-10 \mathrm{~m} \mathrm{~min}^{-1}$. 
The total amount of naturally occurring radioactive radiation (GR) was measured using a total natural gamma ray probe. This GR probe was always run with other probes for depth corrections. One GR curve was chosen as the reference (Master-GR), and all other GR curves with their attached other measurements were shifted to fit the Master-GR. Vertical resolution is approximately $10 \mathrm{~cm}$, and typical penetration into the rock is about $10 \mathrm{~cm}$.

The spectrum of the naturally occurring radioactive radiation (SGR), i.e. uranium, thorium, and potassium, was measured using a natural gamma ray probe. Logging speed was slower than $2 \mathrm{~m} \mathrm{~min}^{-1}$ for the SGR probe to allow gathering of a reliable gamma ray spectrum. Vertical resolution is $\sim 10 \mathrm{~cm}$, and penetration into the rock is $\sim 15 \mathrm{~cm}$. Gamma rays penetrate steel casing; therefore both the GR and the SGR probes could be run in cased holes. Corrections were carried out for the casing as well as for the different diameters of the borehole. Th and $\mathrm{K}$ values are often used as a proxy for a first estimate and characterization of clay content in the sediments (e.g. Wonik, 2001; Ruffell and Worden, 2000; Schnyder et al., 2006), assuming that they are almost exclusively present in this grain-size fraction, and that $\mathrm{K}$ and $\mathrm{Th}$ are present in montmorillonite, illite, and kaolinite in different portions. To estimate the clay content in Lake El'gygytgyn sediments, we used the approaches given by Wonik (2001):

$C_{\mathrm{cl}}(\mathrm{K})=\frac{\mathrm{K}-\mathrm{K}_{\mathrm{sand}}}{\mathrm{K}_{\text {clay }}-\mathrm{K}_{\mathrm{sand}}}$,

and

$C_{\mathrm{cl}}(\mathrm{Th})=\frac{\mathrm{Th}-\mathrm{Th}_{\text {sand }}}{\mathrm{Th}_{\text {clay }}-\mathrm{Th}_{\text {sand }}}$,

with $C_{\mathrm{cl}}=$ clay content $(\%), \mathrm{K}_{\mathrm{sand}}$ and $\mathrm{Th}_{\mathrm{sand}}=\mathrm{K}$ and $\mathrm{Th}$ content of sand, and $\mathrm{K}_{\text {clay }}$ and $\mathrm{Th}_{\text {clay }}=\mathrm{K}$ and $\mathrm{Th}$ content of clay. $\mathrm{K}$ and Th contents of sand are normally very low and were set to $0.1 \%$ for $\mathrm{K}$ and $0.1 \mathrm{ppm}$ for $\mathrm{Th} ; \mathrm{K}$ and $\mathrm{Th}$ contents of clay were set to the maximum $\mathrm{K}$ and Th values measured in the record, which are $4.5 \%$ for $\mathrm{K}$ and $22.4 \mathrm{ppm}$ for $\mathrm{Th}$. $\mathrm{K}$ and Th in Eq. (1) and (2) are the actual readings from the SGR dataset. A third approach uses the GR data as follows (Wonik, 2001):

$V_{\mathrm{cl}}(\mathrm{GR})=0.33 *\left(2^{2 * \mathrm{GRI}}-1\right)$,

$\mathrm{GRI}=\frac{\mathrm{GR}-\mathrm{GR}_{\text {sand }}}{\mathrm{GR}_{\text {clay }}-\mathrm{GR}_{\mathrm{sand}}}$,

with $V_{\mathrm{cl}}=$ percentage of the volume of clay, $\mathrm{GR}_{\mathrm{sand}}=$ $135 \mathrm{API}$ and $\mathrm{GR}_{\text {clay }}=10 \mathrm{API}$; GR in Eq. (4) is the actual reading from the GR dataset.

\section{$3.4 \mathrm{Si} / \mathrm{Ti}$, TOC data}

Silicium/titanium $(\mathrm{Si} / \mathrm{Ti})$ ratios were determined on core halves using an X-ray fluorescence (XRF) core scanner
(ITRAX, Cox Ltd., Sweden). Details on the scanner settings and processing of the data are given in Wennrich et al. (2013). Total organic carbon (TOC) content was calculated as the difference between total carbon and total inorganic carbon using a DIMATOC 200 carbon analyzer (Dimatec Corp.) in aqueous suspension.

\subsection{Statistical analyses}

Statistical analyses were carried out in order to detect statistically differing groups of samples. In a second step, these clusters are then compared with their lithological description and, subsequently, their facies assignment. Due to the rather simple dataset, cluster rather than a PCA analysis was carried out using Matlab ${ }^{\circledR}$ and the implemented statistical toolbox (Mathworks Inc., Version 7.14.0.739). In a first step, downhole logging data (magnetic susceptibility, electrical resistivity, $\mathrm{U}$ counts, Th counts, $\mathrm{K}$ counts) were clustered into 3 groups (clusters 1 to 3 ) using k-mean clustering to allow for a first characterization of the entire record. Data $<143 \mathrm{~m}$ b.l.f. were omitted due to the disturbed magnetic susceptibility and electrical resistivity signal. In a second step, $\mathrm{Si} / \mathrm{Ti}$ ratios, magnetic susceptibilities and TOC percentages measured on the composite core down to approximately $262 \mathrm{~m}$ composite depth were used for statistical clustering in 4 different groups (clusters I to IV), again the kmean clustering method (please note that clusters 1 to 3 and I to IV are two different sets of clusters). For interpretation of the statistically derived clusters, the described facies type was assigned to all samples. Given that sampling occurred generally in $2 \mathrm{~cm}$ steps (Melles et al., 2012), we used the facies type at the mean depth of the sample as representative for the entire sample, neglecting that facies boundaries could also occur within a discrete sample.

\section{Seismic and petrophysical description of the entire lithological succession}

\subsection{Seismic profiles}

The impact crater shows internal geometries as expected for a crater of its size. A central uplift structure interpreted in the form of a central uplift ring structure was revealed by seismic refraction data; it is overlain by an impact breccia (suevite) (Gebhardt et al., 2006). The lacustrine sediments can be divided into two units by means of refraction data; the upper unit is characterized by a seismic velocity of $1550 \mathrm{~m} \mathrm{~s}^{-1}$ and a thickness of about $170 \mathrm{~m}$, the lower unit by $1650 \mathrm{~m} \mathrm{~s}^{-1}$ and a variable thickness of $190 \mathrm{~m}$ on top of the uplift ring structure to $290 \mathrm{~m}$ in the surrounding basin (Gebhardt et al., 2006). For the description of the seismic sections, we follow the stratigraphic numbering introduced by Gebhardt et al. (2006). Unit I comprises all lacustrine sediments and is subdivided into subunits Ia and Ib. Units II and III are the underlying suevite layer and the brecciated bedrock that form 

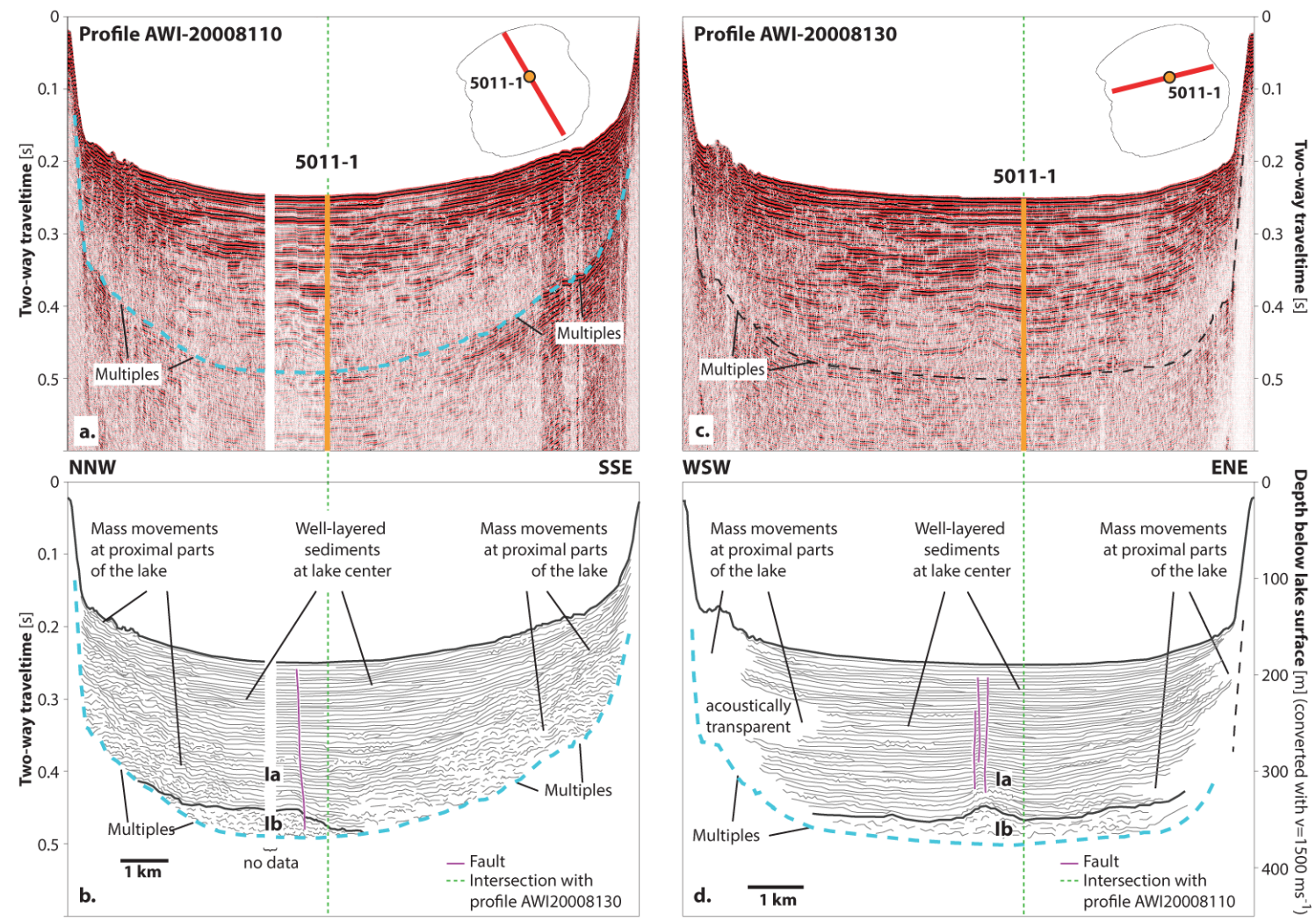

Fig. 2. Single-channel seismic reflection profiles AWI-20008110 and AWI-20008130 (acquired with a Bolt 600B airgun). Seismic profiles are shown in (a) and (c); line drawings and interpretations in (b) and (d). Green dashed line marks the intersection of the two lines that was chosen for drill site 5011-1; lilac lines show the faults that are likely related to the central uplift structure of the impact crater (see Gebhardt et al., 2006). Seismic profiles clearly show the boundary between subunits Ia and Ib. Units II and III are masked by the multiples.

the basement below the lake floor deformed by the impact. The subdivision of unit I into subunits $\mathrm{Ia}$ and $\mathrm{Ib}$ that was indicated by the refraction data by a shift in seismic velocities can also be observed in the reflection data. However, the larger part of $\mathrm{Ib}$ is masked by the multiple in the reflection data. Where observable, seismic reflection data exhibit that upper subunit Ia is well-layered, while lower subunit $\mathrm{Ib}$ is more chaotic and discontinuous (Fig. 2). The lake floor is relatively flat in large parts of the basin, but sometimes rough in the more proximal areas where mass movement deposits occur frequently in the upper layers of the sediments. Mass movement deposits are quite common mainly in the proximal parts of the lake in subunit Ia (e.g. Juschus et al., 2009; Niessen et al., 2007; Sauerbrey et al., 2013), and even in the lake center at the distal 5011-1 drill site, where they make up approximately one third of the entire sediment column (Sauerbrey et al., 2013). In the lower part of subunit Ia, mass movement deposits reach much farther toward the central part of the lake (Fig. 2), whereas in the upper layers they are almost entirely restricted to the proximal part of the lake. This is confirmed by the fact that only small mass movement deposits, mainly turbidites, were found in pilot cores PG1351 ( $\sim 13 \mathrm{~m}$ length) (Melles et al., 2007$)$ and Lz1024 ( $\sim 16 \mathrm{~m}$ length) (Juschus et al., 2009). The turbidites were associated with distant debris flows in a conceptual model (Juschus et al., 2009), which was confirmed by the findings in the drill cores where debris flows are in most cases directly overlain by turbidites (Sauerbrey et al., 2013).

The wide shelf at the southeastern part of the lake is characterized by aggrading sequences; seismic data from the western and northwestern shelf are not available due to coarse sediments limiting acoustic penetration in these areas. Subunit Ia forms onlaps against the steep slope at the lake margins in a layer-cake manner (Fig. 2), gradually muting a formerly deeper surface with steeper relief (Niessen et al., 2007). Subunit Ia conformably overlies subunit Ib with a clear and distinct boundary between the two. Subunit Ib has a massive, acoustically chaotic character and rarely shows internal layering in the parts that are visible in the seismic profiles. Its upper boundary has a hummocky surface probably due to thick, chaotic mass movements in its uppermost parts (Fig. 2). Its lower boundary to unit II lies below the acoustic multiples and is therefore masked. However, refraction data showed that subunit Ib drapes the central uplift structure, which is characteristic for impact craters of this size (Gebhardt et al., 2006). 


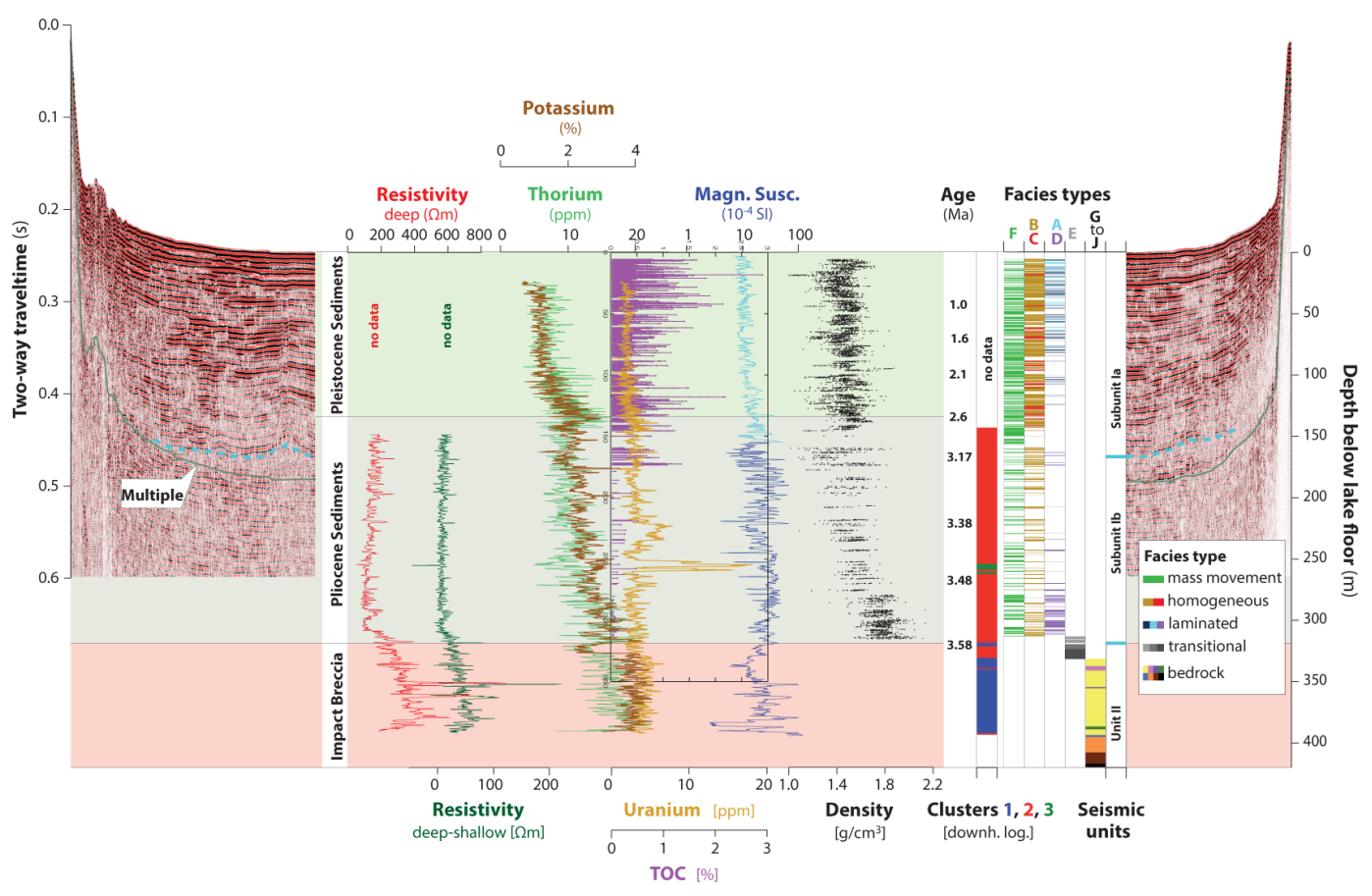

Fig. 3. Single-channel seismic reflection profile AWI-20008130 (acquired with a Bolt 600B airgun) with inset of downhole logging and core physical properties data. Note that the light-blue part of the magnetic susceptibility data derive from direct core measurements, while the dark blue part is from downhole logging measurements - i.e. exact values and amplitudes of the two datasets are not directly comparable. Dashed turquoise horizontal lines mark the boundaries of seismic subunits 1a and 1b; the boundary between units I and II is taken from Gebhardt et al. (2006). Sedimentary facies comprise mass movement deposits (facies F; green), massive interglacial sediments (facies B; ochre), laminated super interglacial sediments (facies C; red), laminated Quaternary glacial sediments representing "cold \& dry" (facies $A_{d}$; light blue) and "cold \& moist" climates (facies $\mathrm{A}_{\mathrm{m}}$; dark blue), laminated Pliocene sediments (facies D; lilac), and transitional sediments between impact breccia and lake sediments (facies E; gray). Facies types are used sensu Melles et al. (2007, 2012) and Brigham-Grette (2013). The impact breccia/suevite succession according to Koeberl et al. (2012) is given as follows: yellow: suevite; lilac: upper volcanic rock layer; violet: lower volcanic rock layer; green: ignimbrite. The clusters derived from k-mean clustering of downhole logging data are shown in blue for cluster 1, red for cluster 2 and green for cluster 3. Ages are taken from Nowaczyk et al. (2013).

Faults with a vertical offset of up to several meters were observed in the central part of the northern profiles in unit I. These show a decreasing offset toward the more recent sediment and are inactive in the upper meters of the lake sediments (Fig. 2); this was also observed in high-resolution subbottom profiles (Niessen et al., 2007). The faults are likely related to the later settling and subsidence of the central uplift structure (Gebhardt et al., 2006).

\subsection{Physical properties from downhole and core measurements}

Subunit Ia comprises the uppermost $\sim 167 \mathrm{~m}$ of the sediment column (Fig. 3), which corresponds to approximately 3.17 Ma (Nowaczyk et al., 2013). This also includes the Pliocene/Pleistocene transition at $123 \mathrm{~m}$ b.l.f. (2.6 Ma). Downhole logging data show that the Pleistocene sediments are characterized by relatively constant $\mathrm{K}$ and Th counts down to approximately $100 \mathrm{~m}$ b.l.f. (2.1 Ma, Nowaczyk et al., 2013); magnetic susceptibilities of the sediment core are highly variable, but fluctuate in a range between $\sim 15$ and $\sim 200 \times 10^{-4}$ SI (Fig. 3). Similar to magnetic susceptibility, density is highly variable throughout the entire record, but scatters around a mean value of approximately $1.5 \mathrm{~g} \mathrm{~cm}^{-3}$ in the sediments of subunit Ia $(<3.17 \mathrm{Ma})$. Lithologies and associated sedimentary facies are characterized by a rapid change between homogeneous (facies B) and laminated (facies A) layers that represent warm and cold phases, respectively (Melles et al., 2007), as well as occasional laminated sediments reflecting peak warm conditions (facies C). These hemipelagic sediments are intercalated by a large number of mass movement deposits of different types such as debris flows and turbidites (Sauerbrey et al., 2013) that become thicker toward the lower boundary of subunit Ia (Fig. 3). Below $100 \mathrm{~m}$ b.l.f., downhole logging $\mathrm{K}$ and Th counts show an increase with increasing depth, with the highest values exactly at the Pliocene/Pleistocene boundary and strongly decreasing values in the uppermost part of the Pliocene sediments. Magnetic susceptibility values of the Pliocene part of subunit Ia show a slight increase in amplitude in comparison to the Pleistocene data. 
Subunit Ib comprises all lacustrine sediments between $167 \mathrm{~m}$ b.l.f. and the boundary to the underlying bedrock at $\sim 320 \mathrm{~m}$ b.l.f. While magnetic susceptibility values of the Pleistocene part of subunit Ia originate from sediment core measurements (MS, light blue in Fig. 3), the values of the Pliocene section were measured in the borehole (BMS, dark blue). The two datasets are not completely comparable in terms of their exact values and amplitudes: it seems as if the lower part has much higher amplitudes; this however might be an artifact caused by the different measurement methods. Magnetic susceptibility seems to be more variable in long-term trends in the Pliocene part of the sediments; however, it is unclear if this is a real paleoclimate signal or just a scaling effect. Unfortunately, there is not enough overlap in between the two datasets to tune them to similar amplitudes. Nevertheless, it is obvious that magnetic susceptibility is much more variable between approximately 150 and $220 \mathrm{~m}$ b.l.f. than below ( $220 \mathrm{~m}$ corresponds to $3.38 \mathrm{Ma}$, Nowaczyk et al., 2013). Electrical resistivity is rather constant throughout the entire Pliocene sediment succession with exception of the lowermost approximately $20 \mathrm{~m}$ where a small maximum occurs at $\sim 300 \mathrm{~m}$ b.l.f. Density shows an increase with increasing depth from mean values around $1.5 \mathrm{~g} \mathrm{~cm}^{-3}$ in the uppermost part of subunit Ib to mean values around $1.8 \mathrm{~g} \mathrm{~cm}^{-3}$ with values as high as $>2.0 \mathrm{~g} \mathrm{~cm}^{-3}$ in the lowermost part, i.e. in the transitional zone between lacustrine and impact-related units. Lithological description of subunit Ib is not as detailed as for subunit Ia due to lower core recovery and, thus, larger drilling-related gaps (for details on drillings operations, see Melles et al., 2011). As in the upper part, sediments alternate between laminated and homogeneous sediments, but the homogeneous facies B dominates the Pliocene part of the record. Only in the lowermost part, i.e. below $\sim 270 \mathrm{~m}$ b.l.f. (3.48 Ma, Nowaczyk et al., 2013; Brigham-Grette et al., 2013), are laminated sediments more abundant. As in subunit Ia, mass movement deposits are intercalated frequently in the hemipelagic sediments.

Uranium values are rather constant throughout the entire record, with slightly higher values in the bedrock. Two strong exceptions however are observed in the lacustrine part: (a) between $\sim 220$ and $\sim 244 \mathrm{~m}$ b.l.f., $\mathrm{U}$ values are slightly enhanced, and (b) a strong double peak is observed between $\sim 251$ and $\sim 262 \mathrm{~m}$ b.l.f. The $\mathrm{U}$ peaks are confirmed by the independently measured total GR.

Electrical resistivity (deep and shallow), borehole magnetic susceptibility, and natural gamma ray counts of $\mathrm{K}$, $\mathrm{U}$ and Th were used for cluster analyses to distinguish among different main units between $143 \mathrm{~m}$ and $394 \mathrm{mb}$ b.l.f. This includes the boundary between the lacustrine sediments and the brecciated bedrock. Three clusters could be distinguished: (1) cluster 1 is characterized by high electrical resistivity and enhanced K content values (Fig. 4 upper panel). Magnetic susceptibility is rather variable. (2) Cluster 2 is characterized by low electrical resistivity, variable magnetic susceptibility, and low U and K content. (3) Cluster 3 has

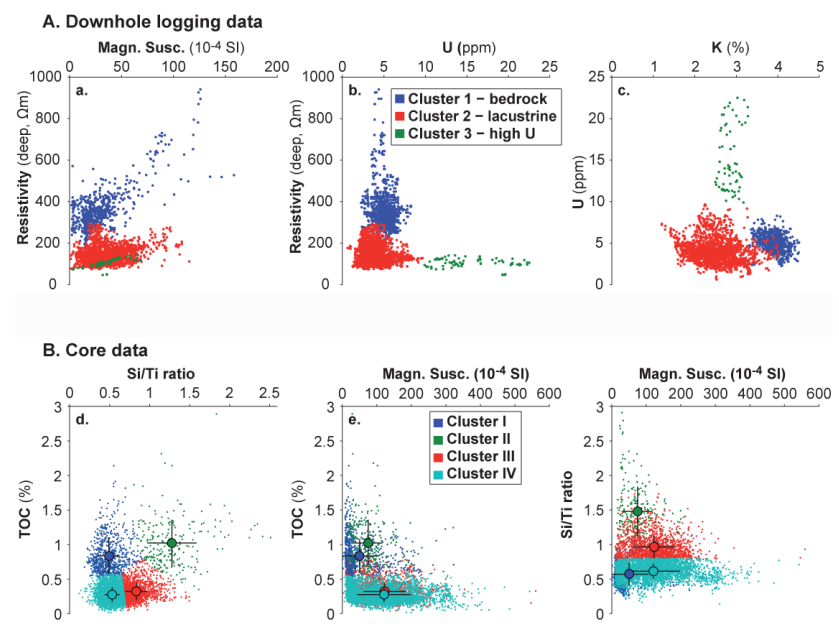

Fig. 4. Crossplots of clusters vs. geophysical and geochemical parameters. Upper panel: clusters 1 to 3 derived from k-mean clustering of downhole logging data (electrical resistivity (deep and shallow), magnetic susceptibility, U, Th, and K counts). Lower panel: clusters I to $\mathrm{V}$ derived from k-mean clustering of core data (TOC content, $\mathrm{Si} / \mathrm{Ti}$ ratio, standardized magnetic susceptibility). In the lower panel, mean and standard deviation of parameters are shown for each cluster.

low electrical resistivity, high $\mathrm{U}$ and intermediate $\mathrm{K}$ values (Fig. 4 upper panel). It is clearly different from cluster 1 in almost all parameters, but coincides with cluster 2 in terms of low resistivity. Plotting these three clusters against depth (Figs. 3 and 5), it becomes obvious that cluster 1 clearly describes the bedrock. Cluster 2 comprises the main part of the lacustrine record. Cluster 3 is part of the lacustrine sediments but comprises only the section between 254.44 and $259.15 \mathrm{~m}$ b.l.f. and between 260.7 and $262.5 \mathrm{~m}$ b.l.f., where the strong $\mathrm{U}$ double peak is observed (Fig. 3).

Both pelagic sediments and mass movement deposits in Lake El'gygytgyn are part of clusters 2 and 3, which implies that these two sediment types do not differ in their petrophysical characteristics. This confirms that the mass movement deposits consist mainly of reworked lacustrine material (Sauerbrey et al., 2013). Enhanced U values in cluster 3 found in the borehole data could not be measured with the ITRAX XRF core scanner in the according core sections, probably due to the scanner's limited ability for measuring U. $\mathrm{U}$ is removed from the water column and buried in the sediment during oxic conditions (e.g. Anderson et al., 1989); this would probably point at high bottom water oxygen levels when these layers were accumulated. This, however, is not confirmed by the sediment description, which does not differ significantly from above or below these layers. Hence, it is more likely that U-rich rocks were eroded in the lake catchment during these periods and transported to the lake by fluvial/eolian rather than gravitational transport processes.

Natural gamma radiation is often measured and used as an indicator for clay content in sediments, based upon the fact 
that $\mathrm{K}$ and $\mathrm{Th}$ are enriched in different clay minerals. This approach, however, does not work in Lake El'gygytgyn sediments where calculated clay values based upon $\mathrm{K}$ and $\mathrm{Th}$ measurements (Eqs. 1, 2, 3 and 4, respectively) do not correlate with conventionally measured clay contents. This can best be explained by the lake's location in a small catchment with short transport paths from the source rock to the accumulation site, which prohibits full weathering of all grains. K-bearing feldspar grains would normally weather into Kbearing clay, so $\mathrm{K}$ would be an indicator for clay solely. In the case of a very short distance from source to sink, K-bearing feldspar grains of probably fine sand or silt size would also end up in the sediment along with clay. This would in turn suggest that the assumption that sand does not contain K (see Eq. 1, Methods section) is wrong in our case.

\subsection{Boundary between bedrock and lacustrine sediments}

The most prominent change in the downhole logging data occurs at the boundary between lacustrine sediments and the underlying altered bedrock at $\sim 320$ m b.l.f. (Figs. 3 and 5 ). While sediments above $\sim 313 \mathrm{~m}$ b.l.f. are clearly lacustrine with alternating homogeneous and laminated layers, intercalated with frequent mass movement deposits, sediments below $\sim 313 \mathrm{~m}$ b.l.f. are a mixture between a sedimentary matrix and reworked impact breccia. The boundary between the lacustrine sediments and the underlying bedrock is thus rather a transitional zone than a sharp boundary. In the upper part of this transitional zone, i.e. $\sim 313$ and $319.8 \mathrm{~m}$ b.l.f. (transitional zone T1 in Fig. 5), lacustrine sediments form the dominant part of the record, while below $319.8 \mathrm{~m}$ b.l.f. (T2 and T3) the record contains mainly reworked impact breccia in a sedimentary matrix (Raschke et al., 2012). Therefore, the formal boundary between the lacustrine and the impact part of the drill core was defined at $319.8 \mathrm{~m}$ b.l.f., between drill runs $97 \mathrm{Q}$ and $98 \mathrm{Q}$. Koeberl et al. (2013) subdivide the part of the transitional zone that lies below this boundary into two subunits, one from 319.8 to 323 (T2 in Fig. 5) and the second from 323 to 331 mb.l.f. (T3) (note that the original depth values from both Raschke et al. (2012) and Koeberl et al. (2013) were shifted downwards by $3 \mathrm{~m}$ to match the depth scale used by the lacustrine El'gygytgyn scientific community). Both subunits show similar lithologies with fine sand-sized grains mainly composed of glass fragments, intercalated with impact breccia and impact melt blocks. All three subunits of the transitional zone (T1 above, T2 and T3 below the formal boundary) are shown in light to dark gray tones of facies type $\mathrm{E}$ in Fig. 5. The boundary between the matrix-dominated (=lacustrine, T1) and the clast-dominated (=impact-related, T2 and T3) sections appears as a sharp boundary in the electrical resistivity and also in the magnetic susceptibility data. Nevertheless, cluster analyses shows that except for two small bands, the entire transitional zone exhibits characteristics that are more

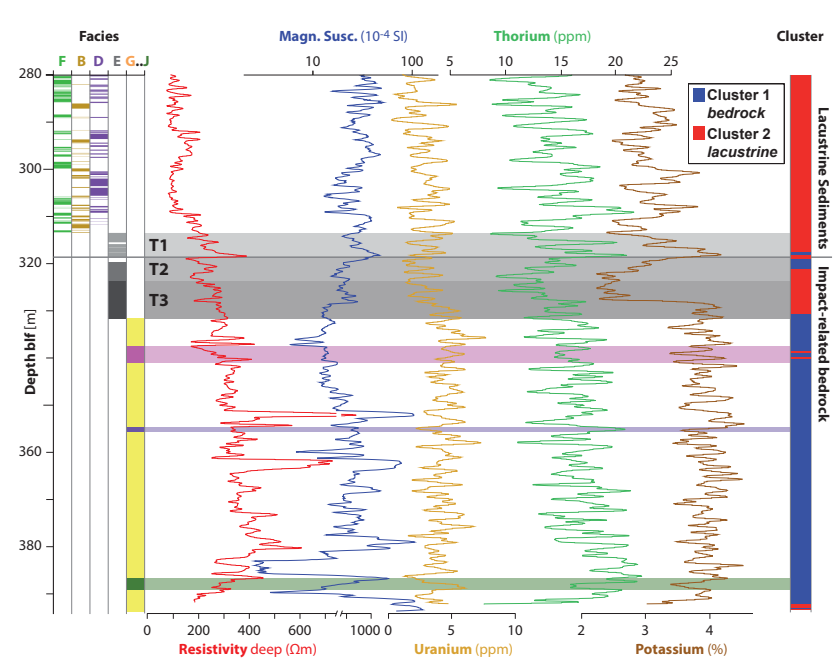

Fig. 5. Facies and downhole logging data of the transitional zone between impact-related bedrock and lake sediments. Facies description as in Fig. 3. Clusters derived from k-mean clustering of downhole logging data are shown in blue for cluster 1 (=bedrock) and red for cluster 2 (= lacustrine). The impact breccia/suevite succession according to Koeberl et al. (2012) is given as follows: yellow: suevite; lilac: upper volcanic rock layer; violet: lower volcanic rock layer; green: ignimbrite.

similar to the overlying lacustrine succession. Only below this transitional zone are the sediments clearly of bedrock affinity.

Chemical elements $\mathrm{K}$ and $\mathrm{Th}$ are enriched just above our formal bedrock-lake sediment boundary, but depleted below with exception of the lowermost part of the transitional zone. Below $331 \mathrm{~m}$ b.l.f., a long succession of suevite was described by Raschke et al. (2012) and by Koeberl et al. (2013). The suevite is obviously petrophysically heterogeneous with highly variable values in both electrical resistivity and magnetic susceptibility (Fig. 5). Two volcanic-like blocks ( 336.83 to 340 and 354 to $353 \mathrm{~m}$ b.l.f.), as well as an ignimbrite block ( 386 to $388.5 \mathrm{~m}$ b.l.f.) described by Koeberl et al. (2013) correspond to peaks in the electrical resistivity data (Fig. 5). Electrical resistivity shows a decreasing trend inside the upper volcanic block towards lower depths, while the opposite is observed in the ignimbrite layer. The former plots into the lacustrine cluster not because it is of lacustrine origin, but quite likely because it differs from the surrounding bedrock; the latter seems to be similar to the surrounding bedrock. Furthermore, electrical resistivity shows that the thick suevite layers have some pronounced internal layers of apparently different geophysical character. 


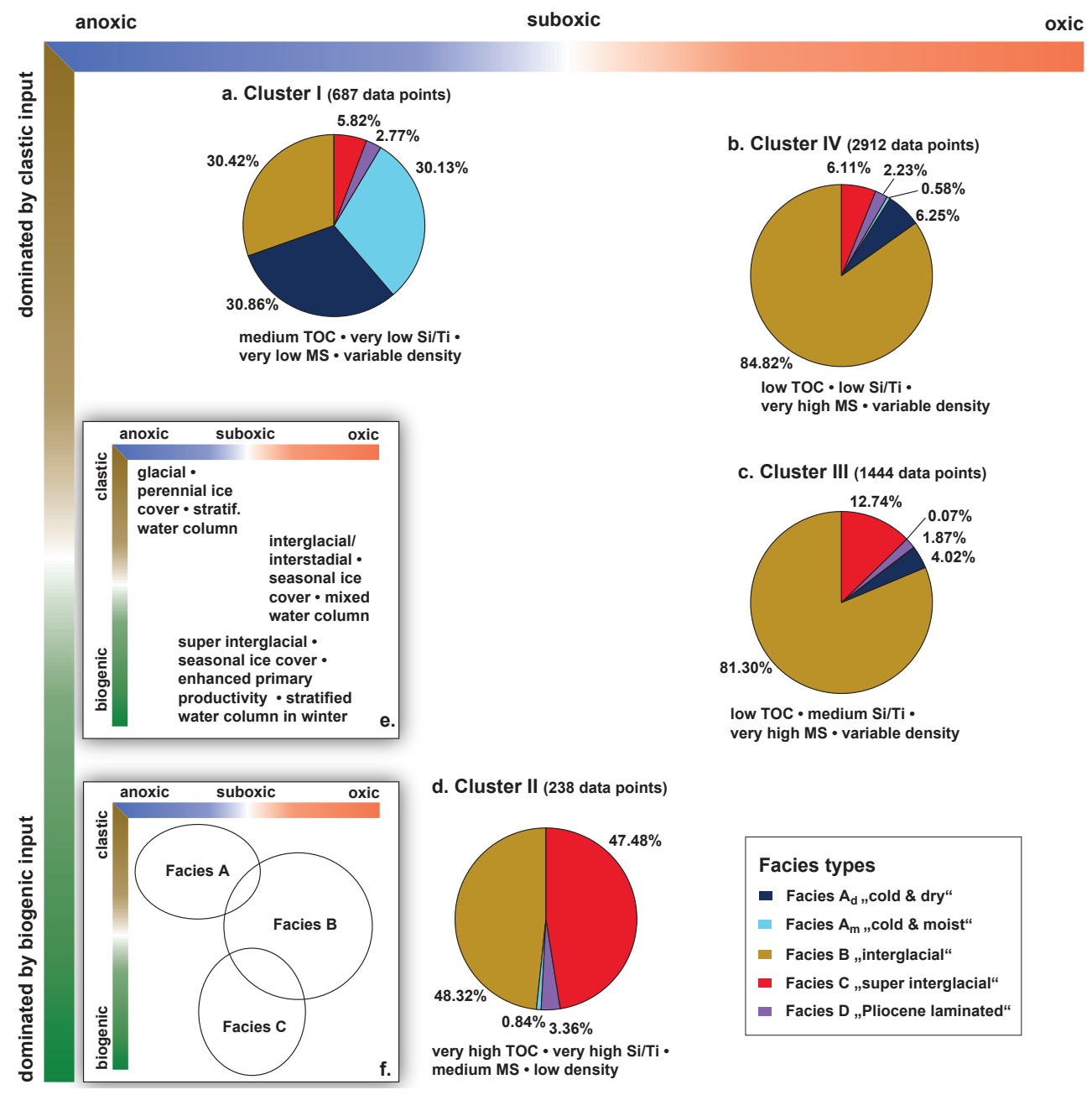

Fig. 6. Pie plots of core-data-derived clusters I to IV versus facies types known from core description. Facies colors correspond to those shown in Figs. 3 and 4. Clusters are distributed according to their redox conditions and clastic vs. biogenic input ratio. (e) shows where different paleoenvironmental conditions would plot in such a redox-condition vs. input-type diagram; (f) shows this for the Melles et al. (2007, 2012) and Brigham-Grette et al. (2013) facies types. Percentages in (a) to (d) are calculated for the facies distribution within each cluster.

\section{Variability in the lacustrine succession}

\subsection{Description of the lacustrine succession}

While electrical resistivity shows pronounced peaks in the bedrock and in the transitional zone, it is fairly constant with only very small peaks throughout the entire lacustrine section, exhibiting some smaller but smooth shifts only in the lowermost part (Figs. 3 and 5). This points at a rather uniform succession of sediments without abrupt changes, even though the sediments are highly variable and change rapidly between homogeneous and laminated layers and mass movement deposits (see facies column in Fig. 3). This is reflected in the fact that almost the entire lacustrine succession is represented by cluster 2 , with only a very small part that has extraordinary high $\mathrm{U}$ values clustering separately into cluster 3 (Fig. 3). The apparent discrepancy between a highly variable sediment and yet quite similar petrophysical characteristics can also be best explained by the lake's location in a rather small catchment of only $293 \mathrm{~km}^{2}$ including the lake's surface (Nolan and Brigham-Grette, 2007). This suggests that during warmer as well as during colder periods the same source rock is eroded, and thus almost all clastic grains that end up in the lacustrine sediments originate from the same provenance. However, there is a minor contribution to the sediment by eolian grains (Francke et al., 2013; Fedorov et al., 2012). In a large catchment, however, one could expect that different parts with different lithologies would experience e.g. variable cover by glaciers or vegetation, and thus result in differing erosion. Nevertheless, differing erosional processes, i.e. more physically dominated weathering during colder and more chemically dominated weathering during warmer periods, in the small hinterland as well as diatom blooms during warmer periods are strong enough to generate highly variable 
Table 1. Amount of data points of the 6 facies types in the 4 clusters (mass movement deposit sediments and tephra were omitted in this table).

\begin{tabular}{lcccccc}
\hline & Facies $\mathrm{A}_{\mathbf{d}}$ & Facies $\mathrm{A}_{\mathrm{m}}$ & Facies B & Facies C & Facies D & Total \\
\hline Cluster I & 212 & 207 & 209 & 40 & 19 & 708 \\
Cluster II & 0 & 2 & 115 & 113 & 8 & 238 \\
Cluster III & 58 & 1 & 1174 & 184 & 27 & 1444 \\
Cluster IV & 182 & 17 & 2470 & 178 & 65 & 2912 \\
\hline Total & 452 & 227 & 3968 & 515 & 119 & 4769 \\
\hline
\end{tabular}

sediment properties (cf. Minyuk et al., 2007) but with almost identical character in terms of petrophysical characteristics. Magnetic susceptibility, in turn, is highly variable in the lacustrine part, probably reflecting different weathering mechanisms and different modes of paleohydrological conditions (such as anoxia in the bottom water; see Melles et al., 2007, 2012) along with dilution effects by biogenic material.

In order to detect the variability within the lacustrine succession related to the different modes in paleoenvironmental conditions, we carried out clustering analyses on 5538 data points using similar parameters as in Melles et al. (2007, 2012). With $\mathrm{Si} / \mathrm{Ti}$ ratio, TOC percentage and magnetic susceptibility from core measurements, we were able to identify four clusters (Tables 1 and 2): cluster I is defined by medium TOC percentages, very low $\mathrm{Si} / \mathrm{Ti}$ ratios and very low magnetic susceptibility. Cluster II shows high TOC percentages along with high $\mathrm{Si} / \mathrm{Ti}$ ratios and medium magnetic susceptibility. Cluster III has low TOC percentages and medium $\mathrm{Si} / \mathrm{Ti}$ ratios along with high magnetic susceptibility. Cluster IV is defined by low TOC percentages and $\mathrm{Si} / \mathrm{Ti}$ ratios combined with high magnetic susceptibility. Density does not vary significantly between clusters I, III and IV, but is considerably lower in cluster II.

\subsection{Paleoclimate implications}

Melles et al. $(2007,2012)$ used TOC percentage, Si / Ti content and magnetic susceptibility to identify the oxygenation state of the bottom water and, thus, whether the water column was mixed or stratified, which in turn gives evidence on the duration of an ice cover on the lake. During phases with a perennial ice cover, the water column could not mix, and depletion of oxygen in the bottom water led to enhanced preservation of organic material, while magnetite underwent dissolution, leading to reduced magnetic susceptibility values. In contrast, during times with seasonal ice cover, mixing of the water column was possible during summer months (as it is today; see Nolan and Brigham-Grette, 2007). Organic carbon was thus consumed in the oxic bottom water, and magnetic minerals were buried without alteration (Melles et al., 2007, 2012). Si / Ti ratios can be used to estimate the biogenic vs. clastic input to the lake (Melles et al., 2012; Wennrich et al., 2013; Brigham-Grette et al., 2013). Enhanced Si / Ti values suggest high biogenic silica contents, which in the case of
Lake El'gygytgyn are produced by enhanced primary productivity, mainly diatoms, during warmer times with only seasonal ice cover. Low $\mathrm{Si} / \mathrm{Ti}$ values indicate colder periods with perennial ice cover, thus limitation in light penetration necessary for photosynthesis, along with probably enhanced clastic input through the 50 small ephemeral inlets around the lake (Melles et al., 2007, 2012). During times with a perennial ice cover, clastic input is triggered by seasonal moats and vertical conduits in the ice, as is the case today when snow melt starts in late spring (Nolan et al., 2003; Asikainen et al., 2007; Francke et al., 2013).

Using this information, we can plot the clusters in a redoxcondition vs. input-type diagram (Fig. 6). In such a diagram, the different modes of paleoenvironmental conditions known from earlier studies by Melles et al. $(2007,2012)$ can be visualized as shown in Fig. 6e and f: the glacial modes of facies A with perennial ice cover and a stratified water column plots into in the upper left corner (anoxic conditions, dominated by clastic input or by a relative dominance of clastic material due to the lack of biogenic input); the interglacial mode of facies B with seasonal ice cover and a mixed water column would show up in the right middle part (oxic conditions with variable, but intermediate contents of clastic and biogenic input), and facies $\mathrm{C}$ - the super interglacial mode - would be found in the lower middle with variably suboxic and oxic conditions and a dominance in biogenic input.

When plotting clusters I to IV into this diagram (Fig. 6), it becomes obvious that sediments of facies B, i.e. the interglacial sediments, plot into several clusters (Fig. 6a to d): a high portion of facies B sediments are found in cluster IV (62.25\% of all facies B data points), and another $29.59 \%$ plot in cluster III. In clusters I and II, some minor percentage $(5.27 \%$ and $2.90 \%)$ of facies B sediments are found. This supports the earlier study by Melles et al. (2012) that describes facies B sediments as highly variable.

Facies F, i.e. the mass movement deposits, also plots into all clusters with the majority in cluster IV $(80.39 \%)$. Almost equal percentages of 10.98 and $8.24 \%$ plot into clusters III and II, and a negligible $0.39 \%$ is found in cluster I. As facies $\mathrm{F}$ is not part of the hemipelagic sediments in Lake El'gygytgyn, it was omitted in the pie plots in Fig. 6 for better visualization of the distribution of facies types A to D in the different clusters. The fact that both facies $\mathrm{F}$ and facies B only have minor parts plotting into clusters I and II, along with the fact that these clusters only represent 13.01 and $4.51 \%$ of all data points, suggests that these two clusters might represent sediment endmembers of Lake El'gygytgyn.

"Glacial" cluster I: cluster I ( 687 data points $=13.01 \%$ of entire dataset, Fig. 6a) plots into a field where sediments of facies A and some of facies B would be assumed. It contains equal amounts $(30.86 \%$ and $30.13 \%)$ of both cold \& dry facies $\mathrm{A}_{d}$ and cold \& moist facies $\mathrm{A}_{\mathrm{m}}$. Another $30.42 \%$ of this cluster comprises sediments that were classified as facies B, i.e. sediments interpreted as accumulated during interglacials, and some $5.82 \%$ were even described as being 
Table 2. Mean and standard deviation (std dev) of total organic carbon (TOC), density, Si / Ti ratio and magnetic susceptibility (Magn. susc.) of clusters I to IV.

\begin{tabular}{|c|c|c|c|c|c|c|c|c|}
\hline & \multicolumn{2}{|c|}{ TOC $\%$} & \multicolumn{2}{|c|}{ Density $\left(\mathrm{g} \mathrm{cm}^{-3}\right)$} & \multicolumn{2}{|c|}{$\mathrm{Si} / \mathrm{Ti}$ ratio } & \multicolumn{2}{|c|}{ Magn. susc. } \\
\hline & mean & std dev & mean & std dev & mean & std dev & mean & std dev \\
\hline Cluster I & 0.8354 & 0.2460 & 1.4791 & 0.1086 & 0.4927 & 0.1404 & 50.1806 & 55.4048 \\
\hline Cluster II & 1.0216 & 0.3369 & 1.2735 & 0.1274 & 1.2826 & 0.3100 & 75.0329 & 41.8939 \\
\hline Cluster III & 0.3215 & 0.1263 & 1.4385 & 0.0949 & 0.8362 & 0.1385 & 122.4036 & 61.3634 \\
\hline Cluster IV & 0.2760 & 0.1076 & 1.4900 & 0.0962 & 0.5327 & 0.0934 & 120.7652 & 76.9754 \\
\hline
\end{tabular}

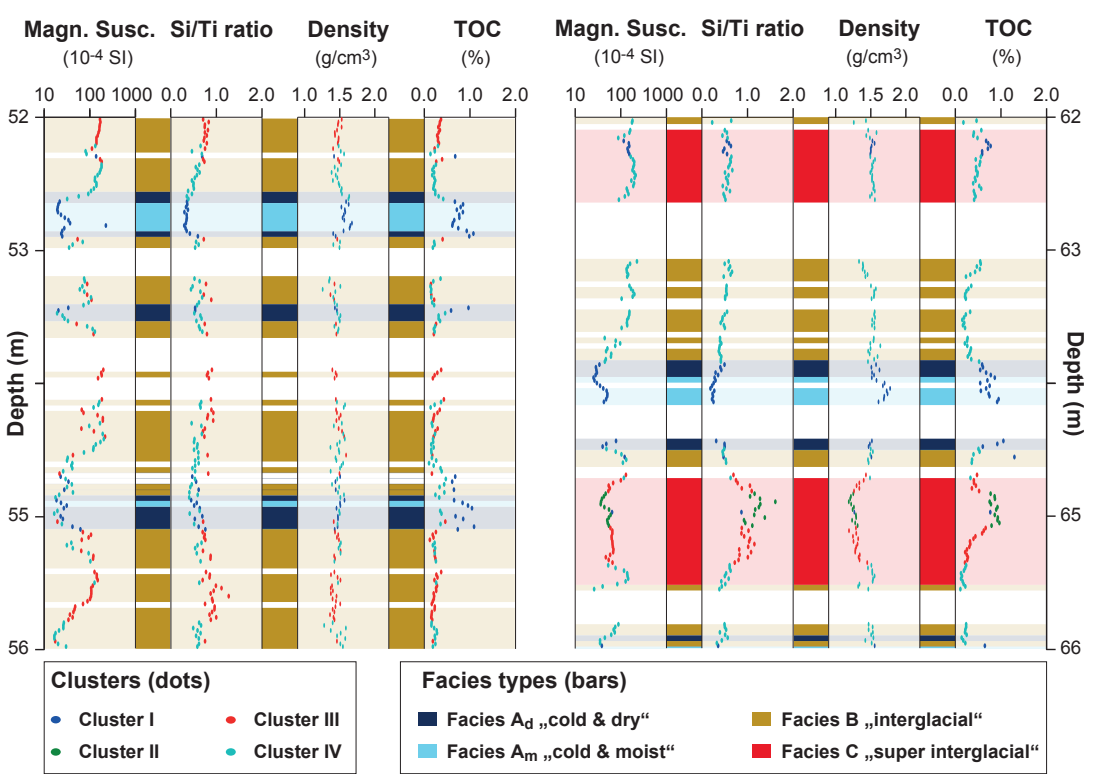

Fig. 7. Downcore distribution of facies types and clusters for 52 to 56 and 62 to $66 \mathrm{mb}$ b.l.f. Facies description as in Fig. 3. Clusters are superimposed on magnetic susceptibility, $\mathrm{Si} / \mathrm{Ti}$ ratio, density and TOC content and are color-coded as in Fig. 4.

from super interglacials (facies C). This suggests that sediments of facies A show similar characteristics as a certain portion of facies B sediments, so they could not be statistically separated by means of cluster analysis. Nevertheless, the part of facies B data that plot into cluster I is only $5.27 \%$ of all facies B data (Fig. 6a) and might even be negligible. In fact, samples used for this study are generally $2 \mathrm{~cm}$ thick, and we chose the facies type of their average composite depth as representative for the entire $2 \mathrm{~cm}$, neglecting that facies boundaries might occur also within samples. Plotting facies types and clusters versus depth (Fig. 7) reveals that cluster I quite well captures the cold phases marked with light- and dark-blue bars in Fig. 7, for example at $\sim 52.5$ to $52.9 \mathrm{~m}$ b.l.f., at $\sim 53.4$ to $53.5 \mathrm{~m}$ b.l.f. and at 63.9 to $64.5 \mathrm{~m}$ b.l.f.

"Interglacial" clusters III and IV: cluster III (1444 data points $=27.34 \%$ of entire dataset, Fig. $6 \mathrm{c}$ ) as well as cluster IV (2912 data points $=55.15 \%$ of the entire dataset, Fig. 6b) have very low TOC contents and high magnetic susceptibility values, pointing at oxic bottom water conditions during their deposition. While in cluster IV $\mathrm{Si} / \mathrm{Ti}$ ratios are low, slightly higher $\mathrm{Si} / \mathrm{Ti}$ ratios in cluster III suggest some biogenic input into the sediment. A high portion of cluster IV is composed of facies B sediment $(84.82 \%)$, and equal parts of 6.25 and $6.11 \%$ consist of facies $A_{d}$ and $C$, respectively. In cluster IV, which is the largest cluster and contains more than half of all data points, facies B is clearly dominant with $81.30 \%$, and $12.74 \%$ are made up of facies $\mathrm{C}$ type sediments along with some $4.02 \%$ of facies $A_{d}$. Both clusters contain the majority of all facies $B$ data points and confirm that this facies type is rather variable yet similar being deposited under oxic conditions. The facies $A_{d}$ sediments found in these two clusters, however, suggest that even during glacial times, oxic (or at least suboxic) conditions in the bottom water were sometimes encountered at least during periods with cold \& dry conditions, and some biological production leading to enhanced $\mathrm{Si}$ / Ti ratios was possible. This is in good agreement with findings by Melles et al. (2007, 2012), who suggested that cold \& dry facies $A_{d}$ represents a perennial ice cover without snow cover. This would allow some light penetration and thus some primary productivity in the water column. In 
contrast, cold \& moist facies $\mathrm{A}_{\mathrm{m}}$ was interpreted as representing a perennial ice cover covered by snow, inhibiting any light penetration into the water column, leading to only very limited photosynthetic life in the lake and thus low TOC values and $\mathrm{Si} / \mathrm{Ti}$ ratios. This, in turn, is confirmed by only negligible 0.58 and $0.07 \%$ of facies $\mathrm{A}_{\mathrm{m}}$ in clusters III and IV, and $0.84 \%$ in cluster II.

"Super interglacial" cluster II (238 data points $=4.51 \%$ of the entire dataset; Fig. $6 \mathrm{~g}$ ): cluster II has significantly enhanced TOC and $\mathrm{Si} / \mathrm{Ti}$ ratios and consists to almost equal parts of facies C and B sediments (47.48 and 48.32\%). The negligible remainder is $3.36 \%$ facies $\mathrm{D}$ and $0.84 \%$ facies $A_{m}$.

While density is rather variable in clusters I, III and IV, it is clearly lower than average in cluster II, which is in good agreement with a high content of biogenic silica. Even though approximately half of cluster II consists of facies C type sediments, only approximately one fifth of all facies type sediments plot into this cluster (21.94\%), while some 35.73 and $43.56 \%$ plot into clusters III and IV. This might either point at a wider range of TOC percentages, $\mathrm{Si} / \mathrm{Ti}$ ratio and magnetic susceptibility values within this facies type, or these samples are highly biased by facies changes within the distinct samples that led to a wrong assignment of facies type to a specific sample. When plotting facies and clusters together vs. depth (Fig. 7) it becomes obvious that only some parts of facies $\mathrm{C}$ (red bars) were captured by cluster II: between $\sim 62$ and $\sim 62.7 \mathrm{mb}$ b.l.f., facies $\mathrm{C}$ sediments were visually described, but have rather low $\mathrm{Si} / \mathrm{Ti}$ content and only slightly enhanced TOC values, so they were statistically gathered into clusters I and IV; these samples are part of the $5.82 \%$ of facies $\mathrm{C}$ samples that were found in cluster I and $6.11 \%$ in cluster IV. On the other hand, sediments of the thick facies $\mathrm{C}$ layer between $\sim 64.7$ and $\sim 65.6 \mathrm{~m}$ b.l.f. show higher $\mathrm{Si} / \mathrm{Ti}$ ratios and TOC content and were therefore gathered into clusters III and II. This would imply that even though facies $\mathrm{C}$ is easily detected by means of visual core description, its basic physical and geochemical properties might not always be significantly different from sediments of other facies types, notably from facies B. Nevertheless, this is in good agreement with findings by Melles et al. (2012) who report that while primary productivity was highest during these extraordinary phases, there are laminae found in the facies $\mathrm{C}$ sediments that suggest at least seasonally suboxic or anoxic conditions in the bottom waters. This could result in a wide variety of TOC percentages and magnetic susceptibility values in the resulting sediment and make it difficult to gather these sediments in one single cluster.

\section{Conclusions}

Seismic reflection profiles of Lake El'gygytgyn exhibit mostly well-stratified sediments with frequent mass movement deposits intercalated in the more proximal areas. The well-stratified acoustic layers correlate with the well-layered sediments of the drill core retrieved during winter/spring 2009 with highly variable facies types changing at high frequency in the core. The lacustrine sediment succession can be separated into two seismic subunits Ia and Ib. Whereas Ia is well-stratified, Ib is acoustically more chaotic and discontinuous. The sediment-bedrock boundary was identified earlier by Gebhardt et al. (2006) at around 320 to $330 \mathrm{~m}$ b.l.f. by means of a seismic-refraction-data-derived depth-velocity model. This was confirmed during drilling, with the first bedrock material found at approximately $320 \mathrm{~m}$ b.l.f.. Downhole logging data down to $394 \mathrm{~m}$ b.l.f., i.e. through the entire lacustrine column and some $74 \mathrm{~m}$ into the bedrock, show that the lacustrine and bedrock part clearly differ in their petrophysical characteristics: cluster analysis separates three clusters, two of which comprise the entire lacustrine succession, while the third contains the bedrock. The boundary between the impact-related bedrock and the lacustrine succession is not sharp, but rather a transitional zone with an upward increasing portion of lacustrine material. Potassium and resistivity values are enhanced in the bedrock section.

In the lacustrine succession, a prominent $U$ peak of unknown origin is visible at around $255 \mathrm{~m}$ b.l.f., and slightly enhanced Th and $\mathrm{K}$ values mark the Pliocene/Pleistocene transition. The core could be clustered into four different clusters (I to IV) down to approximately $262 \mathrm{~m}$ composite depth. The clusters show significant differences in terms of their TOC percentage, $\mathrm{Si} / \mathrm{Ti}$ ratio and magnetic susceptibility, and in some cases also density. This allows plotting the clusters into a redox-condition vs. input-type diagram. In comparison with earlier studies we could conclude that cluster I contains glacial sediments, III and IV sediments from interglacials, and II comprises the sediments from super interglacial intervals.

Acknowledgements. We thank all expedition members of the El'gygytgyn pre-site surveys in 2000 and 2003 as well as of the deep drilling campaign in winter/spring 2009 for their excellent cooperation and support during work at the lake. Funding for this research was provided by the International Continental Scientific Drilling Program (ICDP), the US National Science Foundation (NSF), the German Federal Ministry of Education and Research (BMBF), Alfred Wegener Institute (AWI) and GeoForschungsZentrum Potsdam (GFZ), the Russian Academy of Sciences Far East Branch (RAS FEB), the Russian Foundation for Basic Research (RFBR), and the Austrian Federal Ministry of Science and Research (BMWF). The Russian GLAD 800 drilling system was developed and operated by DOSECC Inc., the downhole logging was performed by the ICDP-OSG, and LacCore, at the University of Minnesota, handled core curation. Financial support for the laboratory analyses was provided by the German Ministry of Education and Research (BMBF grants no. 03G0586B and no. 03G0642B) and the Deutsche Forschungsgemeinschaft (DFG grant no. GE-1924/1-1).

Edited by: J. Brigham-Grette 


\section{References}

Anderson, R. F., Fleisher, M. O., and LeHuray, A. P.: Concentration, oxidation state, and particulate flux of uranium in the Black Sea, Geochim. Cosmochim. Acta, 53, 2215-2224, 1989.

Asikainen, C. A., Francus, P., and Brigham-Grette, J.: Sedimentology, clay mineralogy and grain-size as indicators of $65 \mathrm{ka}$ of climate change from El'gygytgyn Crater Lake, Northeastern Siberia, J. Paleolimnol., 37, 105-122, doi:10.1007/s10933-0069026-5, 2007.

Belyi, V. F.: Impactogenesis and volcanism of the El'gygytgyn depression, Petrology, 6, 96-110, 1998.

Best, A. I. and Gunn, D. E.: Calibration of marine sediment core loggers for quantitative acoustic impedance studies, Mar. Geol., 160, 137-146, 1999.

Brigham-Grette, J., Melles, M., Minyuk, P. S., Andreev, A. A., Tarasov, P., DeConto, R. M., König, S., Nowaczyk, N. R., Wennrich, V., Rosén, P., Haltia-Hovi, E., Cook, T. L., Gebhardt, A. C., Meyer-Jacob, C., Snyder, J., and Herzschuh, U.: Pliocene warmth, polar amplification, and stepped Pleistocene cooling recorded in NE Russia, Science, 340, 1421-1427, doi:10.1126/science.1233137, 2013.

Dansgaard, W., Johnsen, S. J., Clausen, H. B., Dahl-Jensen, D., Gundestrup, N. S., Hammer, C. U., Hvidberg, C. S., Steffensen, J. P., Sveinbjoernsdottir, A. E., Jouzel, J., and Bond, G. C.: Evidence for general instability of past climate from a 250-kyr icecore record, Nature, 364, 218-220, 1993.

Fedorov, G., Nolan, M., Brigham-Grette, J., Bolshiyanov, D., Schwamborn, G., and Juschus, O.: Lake El'gygytgyn water and sediment balance components overview and its implications for the sedimentary record, Clim. Past Discuss., 8, 3977-4001, doi:10.5194/cpd-8-3977-2012, 2012.

Francke, A., Wennrich, V., Sauerbrey, M., Juschus, O., Melles, M., and Brigham-Grette, J.: Multivariate statistic and time series analyses of grain-size data in Quaternary sediments of Lake El'gygytgyn, NE Russia, Clim. Past Discuss., 9, 217-244, doi:10.5194/cpd-9-217-2013, 2013.

Fronval, T. and Jansen, E.: Late Neogene paleoclimates and paleoceanography in the Iceland-Norwegian Sea. Evidence from the Iceland and Vøring Plateaus, in: Proceedings of the Ocean Drilling Program, Scientific Results, edited by: Thiede, J., Myhre, A. M., Firth, J. V., Johnson, G. L., and Ruddiman, W. F., College Station, Texas, USA, 455-468, 1996.

Gebhardt, A. C., Niessen, F., and Kopsch, C.: Central ring structure identified in one of the world's best preserved impact craters, Geology, 34, 145-148, doi:10.1130/G22278.1, 2006.

Geotek: Multi-Sensor Core Logger, available at: http://www.geotek. co.uk/, last access: 13 August 2013, Geotek, 127 pp., 2000.

Glushkova, O. Y. and Smirnov, V. N.: Pliocene to Holocene Geomorphic Evolution and Paleogeography of the El'gygytgyn Lake region, NE Russia, J. Paleolimnol. Special Issue, 37, 37-47, doi:10.1007/s10933-006-9021-x, 2007.

Grootes, P. M., Stuiver, M., White, J. W. C., Johnsen, S. J., and Jouzel, J.: Comparison of oxygen isotope records from the GISP2 and GRIP Greenland ice cores, Nature, 366, 552-554, 1993.

Gurov, E. P., Gurova, E. P., and Rakitskaya, R. B.: Stishovite and coesite in shock metamorphosed rocks of the El'gygytgyn crater in Chukotka, Doklady Academii Nauk USSR, 248, 213-216, 1979a (in Russian).
Gurov, E. P., Valter, A. A., Gurova, E. P., and Kotlovskaya, F. I.: El'gygytgyn impact crater, Chukotka: Shock metamorphism of volcanic rocks (abs.), Lunar and Planetary Science, 10, 479-481, 1979b.

Harris, S. A.: Thermal history of the Arctic Ocean environs adjacent to North America during the last $3.5 \mathrm{Ma}$ and a possible mechanism for the cause of the cold events (major glaciations and permafrost events), Prog. Phys. Geogr., 29, 1-19, 2005.

Herman, Y. and Hopkins, D. M.: Arctic Ocean climate in late Cenozoic time, Science, 209, 557-562, 1980.

Jansen, E., Fronval, T., Rack, F., and Channel, J. E. T.: PliocenePleistocene ice rafting history and cyclicity in the Nordic Seas during the last 3.5 Myr, Paleoceanography, 15, 709-721, 2000.

Juschus, O., Melles, M., Gebhardt, A. C., and Niessen, F.: Late Quaternary mass movement events in Lake El'gygytgn, North-eastern Siberia, Sedimentology, 56, 2155-2174, doi:10.1111/j.1365-3091.2009.01074.x, 2009.

Koeberl, C., Pitarello, L., Reimold, U., Raschke, U., BrighamGrette, J., Melles, M., and Minyuk, P.: El'gygytgyn impact crater, Chukotka, Arctic Russia: Impact cratering aspects of the 2009 ICDP drilling project, Meteor. Planet. Sci., 48, 1108-1129, doi:10.1111/maps.12146, 2013.

Layer, P.: ${ }^{40} \mathrm{Ar} /{ }^{39} \mathrm{Ar}$ age of the El'gygytgyn crater event, Chukotka, Russia, Meteor. Planet. Sci., 35, 591-599, 2000.

Lerman, A., Imboden, D., and Gat, J.: Physics and Chemistry of Lakes, 2nd Edn., Springer, Berlin Heidelberg, 334 pp., 1995.

Melles, M., Brigham-Grette, J., Glushkova, O. Y., Minyuk, P. S., Nowaczyk, N. R., and Hubberten, H.-W.: Sedimentary geochemistry of a pilot core from Lake El'gygytgyn - a sensitive record of climate variability in the East Siberian Arctic during the past three climate cycles, J. Paleolimnol. Special Issue, 37, 89-104, doi:10.1007/s10933-006-9025-6, 2007.

Melles, M., Brigham-Grette, J., Minyuk, P. S., Koeberl, C., Andreev, A. A., Cook, T. L., Fedorov, G., Gebhardt, A. C., Haltia-Hovi, E., Kukkonen, M., Nowaczyk, N. R., Schwamborn, G., Wennrich, V., and the El'gygytgyn Scientific Party: The Lake El'gygytgyn scientific drilling project - conquering Arcric challenges through continental drilling, Sci. Drill., 11, 29-40, doi:10.2204/iodp.sd.11.03.2011, 2011.

Melles, M., Brigham-Grette, J., Minyuk, P. S., Nowaczyk, N. R., Wennrich, V., DeConto, R. M., Anderson, P. M., Andreev, A. A., Coletti, A., Cook, T. L., Haltia-Hovi, E., Kukkonen, M., Lozhkin, A. V., Rosén, P., Tarasov, P., Vogel, H., and Wagner, B.: 2.8 million years of Arctic climate change from Lake El'gygytgyn, NE Russia, Science, 337, 315-320, doi:10.1126/science.1222135, 2012.

Minyuk, P., Brigham-Grette, J., Melles, M., Borkhodoev, V. Y., and Glushkova, O. Y.: Inorganic geochemistry of El'gygytgyn Lake sediments (northeastern Russia) as an indicator of paleoclimatic change for the last $250 \mathrm{kyr}$, J. Paleolimnol. Special Issue, 37, 123-133, doi:10.1007/s10933-006-9027-4, 2007.

Moran, K., Backman, J., Brinkhuis, H., Clemens, S. C., Cronin, T., Dickens, G. R., Eynaud, F., Gattacceca, J., Jakobsson, M., Jordan, R. W., Kaminski, M., King, J. W., Koc, N., Krylov, A., Martinez, N., Matthiessen, J., McInroy, D., Moore, T. C., Onodera, J., O’Regan, M., Pälike, H., Rea, B., Rio, D., Sakamoto, T., Smith, D. C., Stein, R., St John, K., Suto, I., Suzuki, N., Takahashi, K., Watanabe, M., Yamamoto, M., Farrell, J., Frank, M., Kubik, P., Jokat, W., and Kristoffersen, Y.: The Cenozoic 
palaeoenvironment of the Arctic Ocean, Nature, 441, 601-605, doi:10.1038/nature04800, 2006.

Myhre, A. M., Thiede, J., Firth, J. V., Ahagon, N., Black, K. S., Bloemendal, J., Brass, G. W., Bristow, J. F., Chow, N., Cremer, M., Davis, L., Flower, B., Fronval, T., Hood, J., Hull, D., Koç, N., Larsen, B., Lyle, M., McManus, J., O’Connel, S., Ostermann, L. E., Rack, F. R., Sato, T., Scherer, R., Spiegler, D., Stein, R., Tadross, M., Wells, S., Williamson, D., Witte, B., and Wolf-Welling, T.: Proceedings of the Ocean Drilling Program, Initial Reports, Leg 151, Ocean Drilling Program, College Station, Texas, 926 pp., 1995.

NGRIP members: High-resolution record of Northern Hemisphere climate extending into the last interglacial period, Nature, 431, 147-151, 2004.

Niessen, F., Gebhardt, A. C., Kopsch, C., and Wagner, B.: Seismic investigation of the El'gygytgyn impact crater lake (Central Chukotka, NE Siberia): preliminary results, J. Paleolimnol. Special Issue, 37, 49-63, doi:10.1007/s10933-006-9022-9, 2007.

Nolan, M. and Brigham-Grette, J.: Basic hydrology, limnology, and meteorology of modern Lake El'gygytgyn, Siberia, J. Paleolimnol. Special Issue, 37, 17-35, doi:10.1007/s10933-006-9020-y, 2007.

Nolan, M., Liston, G., Prokein, P., Brigham-Grette, J., Sharpton, B., and Huntzinger, R.: Analysis of lake ice dynamics and morphology on Lake El'gygytgyn, NE Siberia, using SAR and Landsat, J. Geophys. Res., 107, 8162, doi:10.1029/2001JD000934, 2003.

Nowaczyk, N. R., Minyuk, P., Melles, M., Brigham-Grette, J., Glushkova, O., Nolan, M., Lozhkin, A. V., Stetsenko, T. V., Andersen, P. M., and Forman, S. L.: Magnetostratigraphic results from impact crater Lake El'gygytgyn, northeastern Siberia: a 300 kyr long high-resolution terrestrial palaeoclimatic record from the Arctic, Geophys. J. Int., 150, 109-126, 2002.

Nowaczyk, N. R., Melles, M., and Minyuk, P.: A revised age model for core PG1351 from Lake El'gygytgyn, Chukotka, based on magnetic susceptibility variations correlated to northern hemisphere insolation variations, J. Paleolimnol. Special Issue, 37, 65-76, doi:10.1007/s10933-006-9023-8, 2007.
Nowaczyk, N. R., Haltia, E. M., Ulbricht, D., Wennrich, V., Sauerbrey, M. A., Rosén, P., Vogel, H., Francke, A., Meyer-Jacob, C., Andreev, A. A., and Lozhkin, A. V.: Chronology of Lake El'gygytgyn sediments, Clim. Past Discuss., 9, 3061-3102, doi:10.5194/cpd-9-3061-2013, 2013.

Raschke, U., Reimold, W., Zaag, P., Pitarello, L., and Koeberl, C.: Lithostratigraphy of the impactite and bedrock section in ICDP drill core D1c from the El'gygytgyn impact crater, Russia, Meteor. Planet. Sci., submitted, 2012.

Repenning, C. A. and Brouwers, E. M.: Mid-Pliocene to Late Pleistocene changes in the Arctic Ocean borderland ecosystem, Program with Abstracts, 251, INQUA, Ottawa, 1987.

Ruffell, A. and Worden, R.: Palaeoclimate analysis using spectral gamma-ray data from the Aptian (Cretaceous) of southern England and southern France, Palaeogeography Palaeoclimatology Palaeoecology, 155, 265-283, 2000.

Sauerbrey, M. A., Juschus, O., Gebhardt, A. C., Wennrich, V., Nowaczyk, N. R., and Melles, M.: Mass movement deposits in the 3.6 Ma sediment record of Lake El'gygytgyn, Far East Russian Arctic: classification, distribution and preliminary interpretation, Clim. Past Discuss., 9, 467-505, doi:10.5194/cpd-9-4672013, 2013.

Schnyder, J., Ruffell, A., Deconinck, J.-F., and Baudin, F.: Conjunctive use of spectral gamma-ray logs and clay mineralogy in defining late Jurassic-early Cretaceous palaeoclimate change (Dorset, U. K.), Palaeogeogr.Palaeocli. Palaeoecol., 229, $303-$ 320, doi:10.1016/j.palaeo.2005.06.027, 2006.

Svensson, A., Bigler, M., Kettner, E., Dahl-Jensen, D., Johnsen, S., Kipfstuhl, S., Nielsen, M., and Steffensen, J. P.: Annual layering in the NGRIP ice core during the Eemian, Clim. Past Discuss., 7, 749-773, doi:10.5194/cpd-7-749-2011, 2011.

Wennrich, V., Minyuk, P. S., Borkhodoev, V., Francke, A., Ritter, B., Raschke, U., Nowaczyk, N. R., Schwamborn, G., Brigham-Grette, J., Melles, M., and El'gygytgyn Scientific Party: Pliocene to Pleistocene climate and environmental history of Lake El'gygytgyn/NE Russia based on high-resolution inorganic geochemistry data, in preparation, 2013.

Wonik, T.: Gamma-ray measurements in the Kirchrode I and II boreholes, Palaeogeogr. Palaeocli. Palaeoecol., 174, 97-105, 2001. 